in summer and behind which they hunted in winter. As a whole, tiney are divided into two exogamous phraties with matrilineal descent, one called Raven, the other usually Wolf, and in the north Eagle as well. One small group outside both phraties could marry into either. Each was subdivided into clans or consanguineal bands, which originally appear to have occupied a particular camp. The larger geographical groups contained members of both phraties, and usually numerous clans. Finally, the clans are subdivided into house groups. Each clan claimed a few distinctive carvings and names; occasionally they might be borrowed. The house names and clan names were generally distinct, and confined to their respective phratry, but a man sometimes claimed the right to the house name owned by his paternal grandfather's clan, so that names sometimes go out of the clan. Those of a man's own phratry are called "friends," those of the opposite phratry "opposites" or "my outside shell." A list is given of the relationship terms. The importance of the phratry system is indicated by the rules of etiquette and the hospitality shown towards members of the same phratry, and the performance by the opposite phratry of certain functions at birth and death.

A mourning feast is given to members of the opposite phratry, food being put into the fire for the spirit of the deceased. All property given away or destroyed at a feast was dedicated to some dead person, who then actually received its spiritual counterpart. A Tlingit employed his opposites to do everything-put up his house and pole, pierce the lips and cars of his children, and initiate them into the secret societies. The sccret society dances were imported from the south, but their observance by no means reached the importance attained among the Kwakiutl and Tsimshian. Whistles were essential concomitants of these dances. The putting up of a house or pole, and the accompanying secret society performance, feasts, and distributions of property were all undertaken for the sake of dead members of a man's clan. Rivalries between opposing parties of dancers at a potlatch often resulted in serious conflict, but the host's people often prevented them by rushing between them bearing their emblem or making the call of the phratry animal.

A. C. $\mathrm{H}$.

\section{RECENT PUBLICATIONS ON AGRICULTURE FROM INDIA AND CEYLON.}

THE recent issues of Circulars and Agricultural Journal of the Royal Botanic Gardens, Ceylon, contain interesting papers on cotton, Hevea brasiliensis, and other native crops. Mr. Lock issues a concise guide to the plots on the Experiment Station, Peradeniya, which will prove useful to visitors, and will, we hope, be the forerunner of a work setting out the general results obtained in the Ceylon experiments and the conclusions to be drawn from them. Mr. Petch deals with certain abnormalities in Hevea brasiliensis. Nursery plants with twisted stems are frequently sent in for examination and report. The stem generally makes a complete turn at the base, either in a regular curve or a combination of curves and abruptly angular bends; in other cases there are two complete turns, and in a single instance three have been observed. It was found possible to reproduce some of these abnormalities by varying the position of the seed in the soil. The insect pests-which mainly attack the root, since the rest of the plant is to a large extent self-protected by the viscid caoutchouc-producing latex-are dealt with by $\mathrm{Mr}$. E. Ernest Green. Mr. Bamber deals in one pamphlet with tapioca, describing its method of cultivation in Malacca, and in another with the cultivation of stronggrowing plants to overrun and "choke" weeds in rubber plantations. The plants suggested are Passiflora foetida and Mikania scandens; crotolaria is also used. When growth has attained its maximum, and before the plants die down, the whole mass of material, usually 12 inches to is inches deep, can be rolled up like a huge carpet, leaving the surface soil quite free from weeds. Mr. Jowitt describes several of the oil-yielding grasses, and Mr. Stewart McCall puts in a plea for the more extensive cultivation of cotton. Altogether the papers are fully up to the high standard tve have learnt to associate with Peradeniya.

$$
\text { NO. } 2077 \text {, VOL. SI] }
$$

It has already been remarked in these columns that the Agricultural Journal of India ranks for general excellence among the best agricultural publications in the world, and the recent numbers in no way alter the impression. The list of articles includes several dealing with improved methods of cultivating cotton and paddy, besides a well illustrated paper on improved implements of home-make adapted to the special conditions of the native cultivator. Mr. Maxwell-Lefroy deals with Eri or castor silk, and Mr. Marsh discusses certain indirect benefits of irrigation not generally recognised. Among these are the possibility of substituting new sowings in case of accidents to advanced crops, the certainty of fodder for the cattle, which are among the worst sufferers in time of drought, and the general improvement of the people and country which inevitably results when the conditions of life become stable. The journal is issued quarterly from Pusa, and the articles are well written from a general point of view it may be confidently recommended to all interested in Indian affairs.

Probably no publication could give a better idea of the enormous size of India, and the great diversity of conditions, than the two volumes of agricultural statistics brought out by the Government of India. The first volume deals with British India, and contains 429 folio pages of closely printed figures; the second contains the records of native States, and is smaller. Comparing the year $1906-7$ with $1897-8$, the earliest given in the volume, we find the following areas, in acres :-

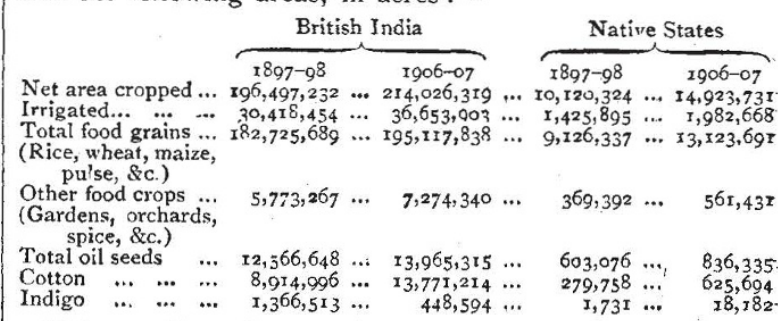

This steady, all-round increase in the area under the various crops furnishes abundant proof of the increasing prosperity of India, and must be a source of great gratification to the British administrators and advisers through whose labour it has been made possible. The one exception in the general prosperity is indigo. During the ten years the area has shrunk from more than one and a third million to less than half a million acres. The indigo planters are a highly enlightened body, and look to science to help them save the industry; their fortunes are very much involved in the contest now going on between the agricultural chemist and the synthetical organic chemist.

\section{POSITION FINDING WITHOUT AN HORIZON.}

THE Journal Ila of July I7-an aëronautical journal published at Frankfort-contains an article which in some respects is supplementary to that on the subject of position finding without an horizon which appeared in NATURE of July 22, or, as this article was the later in time, perhaps it would be more correct to say that it was supplementary to the one in Ila. The latter, which is written by Dr. Alfred Brill, relates to the reduction of observed altitudes for the purpose of finding position by means which can be quickly and readily effected in a balloon. After showing the inconvenience of the usual trigonometrical methods used on board ship, and how tiresome the use of tables must be which correlate time, latitude, declination, and altitude, he proceeds to describe his method, which is one eminently suitable and convenient, that is, where a graphic method is sufficiently accurate.

Dr. Brill employs a circular map of, say, Central Europe on transparent celluloid, the projection being one of least distortion. Before and behind this are two more sheets of celluloid, with the Sumner equal altitude circles drawn on the same projection. These sheets each have a central longitudinal azimuth line, while the map is provided with a circle of degrees round its periphery. The two Sumner sheets can be moved longitudinally on rollers like blinds, and these two and the included map may be turned in 